\title{
Богословская антропология по учению митрополита Сурожского Антония (1914-2003)
}

\section{ANTROPOLOGIA TEOLOGICZNA METROPOLITY SUROSKIEGO ANTONIEGO (1914-2003)}

Metropolita Suroski Antoni (1914-2003) naucza, iż człowiek już przed poczęciem znajduje się w pewnej relacji z Bogiem; Bóg tworzy człowieka z niebytu do bytu, na swój obraz i podobieństwo, w pełni Boskiej miłości, zobowiązując go do przemiany siebie i otaczającego świata. Historia Starego Testamentu ukazuje proces wzrastania w człowieczeństwie, gdzie grzech przeplata się z Bożą prawdą. Uwieńczeniem tego etapu jest Wcielenie Bożego Syna, które otwiera ludzkości drogę ku wieczności. Autentycznym przykładem dla chrześcijan są święci, którzy poprzez modlitwę i życie duchowe uczą realizacji postawy miłości Boga, siebie i bliźniego. Ostatecznym powołaniem człowieka jest udział w Boskiej naturze.

Słowa kluczowe: antropologia, antropologia teologiczna, Metropolita Suroski Antoni (1914-2003).

Митрополит Антоний ${ }^{1}$ утверждает, что человек не сотворен объективно, как предмет; еще до начала существования человек находится в некоем вза-

Митрополит Антоний родился в 1914 году. Первые годы своей жизни провел в Персии, так как его отец был российским консулом. В связи с революцией, после скитаний по Европе, семья в 1923 году осела в Париже, где Антоний окончил среднюю школу, а также биологический и медицинский факультеты университета. 
Antropologia teologiczna

имоотношении с Богом. Бог творит человека, так как человек ему желанен; не для того, чтобы Бог был Богом, не из необходимости вызывать человека из небытия, ведь Господь был бы той же полнотой самодовлеющего бытия и торжествующей, ликующей жизни и без человека. Бог творит человека для, но не для Себя².

Уже в Предвечном Совете, вызывающем человека к бытию, покоится полнота Божественной любви. В момент творения Господь знал, что смерть и страдания достигнут человека. Знал также, что Божья любовь носит крестный оттенок; в этой любви есть радость давать и радость получать, а также есть победоносная, трагическая радость Креста. То есть уже в момент творения человек возлюблен крестной Божественной любовью, он желанен. „Это акт царственной, творческой свободы. И в том, что мы Богу не необходимы, лежит основа какой-то хотя бы относительной самобытности нашей. Если мы были бы необходимы Богу, если бы без нас, без твари, Бог не был полнотой того, что Он есть, - мы были бы только жалкой тенью в этом сиянии, мы были бы словно светлячки при ярком солнце. Правда, мы горели бы каким-то светом, но по сравнению с Светом Невечерним, сиянием Солнца правды, полуденным озарением Божества мы были бы предельно ничтожны. Потому именно, что мы не необходимы, мы имеем некоего рода самобытность"з.

Человек создан для диалога с Господом; конечным призванием человека - участие в Божественной природе (см. 2 Пет. 1, 4). Согласно Святому Писанию, человек сотворен из ничего, из небытия к бытию ${ }^{4}$. Перед ним открыты

В 1939 году принес тайные монашеские обеты. В 1943 году пострижен в мантию с именем Антония. Во время второй мировой войны - врач в антигитлеровском движении Сопротивления. По окончании войны до 1948 года продолжал медицинскую практику.

В 1948 году принял рукоположение в священники и был направлен на пастырское служение в Великобританию. В 1957 году рукоположен в епископы, с 1966 по 1974 годы - Митрополит и Патриарший Экзарх в Западной Европе. Всю свою дальнейшую жизнь посвятил пастырскому труду в епархии. Умер 4 августа 2003 года. Ср. Митрополит Антоний Сурожский, Быть христианином, Москва 2010, с. 3-4. См. А. Кырлежев, Мистик в миру, [в:] Митрополит Сурожский Антоний, Человек перед Богом, Москва 2013, с. 10-26. См. Фонд „Духовное наследие митрополита Антония Сурожского”, Библиотека-фонд „Русское Зарубежье”, Духовное наследие митропотита Антония Сурожского. Материаль Первой международной конферениии 28-30 сентября 2007 г. Москва, Москва 2008.

Ср. Митрополит Сурожский Антоний, О некоторых категориях нашего тварного Бытия, [в:] idem, Человек, Москва 2012, с.6.

Ibidem, c.7-8.

Митрополит Антоний считает, что „в этом есть, с одной стороны, бесконечная наша бедность и, с другой - всерадостное наше богатство. Бедность - потому что мы ничем не обладаем, потому что у нас нет корней ни в чем (я сейчас говорю не только о 
все просторы и он ничем не владеет. В этом автор видит начало Царства Божия, о чем напоминает первая заповедь блаженства: „Блаженны нищие духом, яко тех есть Царство Небесное” (Мф. 5, 3). Иоанн Златоуст учит, что Antropologia teologiczna беден не тот, у кого ничего нет, а тот, который желает того, чего не имеет. Митрополит Антоний рассуждает: „Можно не обладать ничем и не быть бедным; можно быть богатым с точки зрения каждого, кто посмотрит на нашу жизнь, и чувствовать себя обездоленным бедняком. Мы богаты только тогда, когда воспринимаем все, что нам дано в жизни, как дар Божий, как богатство любви Господней"5.

Митрополит Антоний приводит рассказ Мартина Бубера (1875-1965) - еврейского религиозного философа и писателя, профессора Тель-Авивского университета, о раввине, который жил в Польше в XVIII веке и был крайне, отчаянно беден, но каждый день благодарил Господа за все Его щедрые дары. На вопрос, как может он благодарить Бога в молитве, ничего не имея, раввин ответил: „Господь воззрел на мою душу и увидел, что, для того чтобы я вырос в полную свою меру, мне нужна бедность, голод, холод и оставленность; и этим Он меня одарил безмерно”. Митрополит Антоний видит в этом раввине человека, сумевшего верить Богу и Его любить, не взирая на свою обездоленность ${ }^{6}$.

Открытие Царства Божия наступает в момент радикального и абсолютного сознания о необладании ничем, а жизнь, данная человеку, также является даром Божиим. „Мы не можем ее создать, мы не можем ее защитить, мы не можем ее сохранить и удержать. Тело наше вне нашей власти. Достаточно маленькому сосуду разорваться у нас в голове, чтобы самый великий ум поблек и человек стал хуже зверя. Бывает перед нами горе, нужда, и мы всеми силами хотели бы почувствовать сострадание...” . По суждению митрополита Антония, при всей окончательной обездоленности человек на деле не обездолен. Главное понять, что все что он имеет, является знаком

человеке, а обо всей твари). Мы не коренимся в Боге, мы от Него глубоко различны. Мы не коренимся ни в чем, что существовало бы до нас, до твари вообще. По слову Митрополита Филарета Московского, мы повешены между двумя безднами, между бездной Небытия и Божественной бездной, только на слове и воле Господних. По существу, мы до конца беспочвенны; и мы можем иметь корни, только если станем действительно своими и родными Богу, причастниками Божественной природы, живыми членами Тела Христова, храмами Святого Духа, детьми Отчими по приобщению, то есть все вместе - Церковью, и каждый из нас - живым членом этой Церкви. Каждый из нас, но не порознь, потому что здесь именно нельзя употребить слово порознь, - розни нет, есть всепобеждающее единство во Христе и Духе, так что наша жизнь сокрыта со Христом в Боге (Кол 3,3$)$ ”. Ibidem, c. 8-9.

Ibidem, c. 9.

Ibidem, c. 10-11. 
Antropologia teologiczna

Божественной любви в каждый момент его жизни. Только тогда раскрывается Божие Царство, где „над всеми и над всем Сам Господь, Который дарствует без конца".

Человек создан по образу и подобию Божию. По словам митрополита Антония, каждый является освященной иконой, раненой, обезображенной, но в то же время оставаясь святыней и образом Божиим. Задача христианина - „вглядеться во все то, что в этой иконе уцелело, и эту икону обновить, как бы реставрировать" ". Чтобы быть похожим на Господа, человеку, по словам митрополита Антония, необходимо вчитываться в Библию, „искать, что в этом Писании вызывает в нас трепет, восторг, радость, на что мы отзываемся, говоря: „Боже, как это прекрасно! Как это истинно! Как это светло!..” Потому что, когда мы так можем отозваться на то или другое евангельское сказание, это значит, что Бог и мы - в гармонии, что мы душевно одно, что тут мы коснулись нашего подобия с Ним, и Он нам подобен. Мы коснулись Его человечества и узнали в Нем себя, но - в чистоте, во славе, в красоте, в истине. И когда мы это находим, мы не смеем больше поступать иначе как в послушании этому откровению"

Человеку поручено довести до совершенства творение, созданное Богом. Митрополит напоминает о словах святого Максима Исповедника о принадлежании человека двум мирам: телом своим - земле, а душой, духом - Божественному миру ${ }^{11}$. Призвание человека, на что заостряет внимание митрополит Антоний - в уходе в глубины Божии, в роднении с Христом, чтобы через единство с Господом преобразить свою телесность и окружающий мир. В этом наш автор видит главную задачу христианина ${ }^{12}$.

В таком случае почему человек малоуспешен в своем призвании? Митрополит Антоний причину находит в Священном Писании. Иисус во время искушения дьяволом в пустыне сказал: „Не хлебом единым будет жив

8

Ibidem, c. 11-12.

„Если Бог так в нас мог поверить, то мы должны верить в себя, но не в свои человеческие силы, не в свои способности. Мы не должны быть ослепленными теми кажущимися нам драгоценными качествами, которые у нас есть, качествами ума, воли, творчества; мы должны быть внимательны к тому сокровенному сердца человеку $(1$ Пет. 3,4), который является тайной нашей. Святой Ефрем Сирин говорит, что, когда Бог творит человека, Он вкладывает в глубины его все Царство Божие, и задача жизни в том, чтобы копать глубже, пока не найдешь это сокровище. Мы обязаны верить в себя, потому что Бог в нас верит. Мы обязаны искать в себе то, что Божие, - не только то, что Ему принадлежит; все Ему принадлежит по праву, - но искать в себе все то, что нас делает родными Ему, сродняет с Ним, уподобляет нас Ему, делает нас на Него похожими”. Idem, Вера Божия в человека, [в:] Idem, Пути христианской жизни, Москва 2011, с. 142-143.

10 Ibidem, c. 143-144.

11 Cp. idem, Бог в нас верит, Москва 2010, с. 40.

12 Cp. idem, О призвании человека, в: Idem, Человек перед Богом, Москва 2013, с. 357-358. 
человек, а всяким словом Божиим" (Лк. 4, 4). Трагедия произошла в момент отпадения человека от Бога. „Когда Ева была сотворена из Адама, они друг на друга посмотрели и Адам сказал: это плоть от плоти моей, кость от кости Antropologia teologiczna моей (Быт. 2, 23). То есть он увидел в ней себя самого, но уже не замкнутого в себе, а как бы перед собой, он увидел в ней не свое отражение, а собственную ее реальность. И Ева также. И они были едины. Грех не только их разделил, но и разбил цельность отношений человека со всем окружающим миром"13.

Митрополит Антоний подчеркивает, что из-за упадка человечества мир стал безобразным, уродливым, страшным, а смерть получила неограниченную власть. Господь не создал человека на смерть и уничтожение, но для вечной жизни. Человек призван к бессмертию - „не только к бессмертию воскресения, но и к бессмертию, которое не знало смерти”. Смерть является следствием греха, когда человек отвернулся от Бога и стал искать путь вне Бога, пробуя сам приобрести знание без приобщенности знанию и мудрости Божиим. Если с одной стороны смерть чудовищна, то с другой в момент смерти наступает конец разлуке с Господом. Врата смерти позволяют „избежать порочного круга бесконечности в отделенности от Бога, от полноты [...] вырваться из тварной бесконечности, в которой нет пространства, чтобы снова стать причастниками Божественной жизни, в конечном итоге - причастниками Божественной природы"14.

В Ветхом Завете мы видим, как грех человека переплетается с правдой Божией, а много вдохновения и красоты - с многим страшным и уродливым. И наступает момент, когда сам Бог входит в историю, Сын Божий становится Сыном человеческим, а Слово - плотью. Несмотря на упадок, Бог верит в человека, до такой степени, что Сам воплощается. „Бог в нас верит, Бог стоит стражем нашего человеческого достоинства, Бог - хранитель нашей чести, и ради того, чтобы мы могли в это поверить, это увидеть воочию, наш Бог становится обездоленным, беспомощным человеком. Только те, которые верят в силу и ни во что иное, только те, которые верят в свою праведность, не найдут пути к Нему, пока не покаются, пока не увидят, что смирение, любовь, жалость, милосердие - закон жизни"15.

Христос явил миру смирение, любовь Божию и веру во всю тварь, подчеркивая огромную ценность каждого человека. Благодаря этому человек имеет возможность быть во всю меру Христова воплощения, рассматривая окружающий его мир как бы „видимое одеяние Божества, когда будет Бог во всем” (см. 1 Кор. 15, 28) ${ }^{16}$. Христос в течение 33-летнего периода является в полном смысле совершенным Человеком, так как Он одновременно

13 Ibidem, c. 358 .

14 Idem, Жизнь. Болезнь. Смерть, Москва 2012, с. 54-56.

15 Idem, Бог в нас верит..., ор. cit., с. 51.

16 Ibidem, c. 52. 
и совершенный Бог. Каждый, пока не соединится неразлучно, навсегда, до самых глубин с Богом, все еще находится на пути своего очеловечения. Только Христос - Человек в полном смысле этого слова, потому что Он - Богочеловек ${ }^{17}$.

Митрополит Антоний подчеркивает особое значение слов святого апостола Павла: „Жизнь для меня - Христос, смерть - приобретение, потому что, живя в теле, я отделен от Христа..." Смерть - это не конец, а начало, это дверь в простор вечности, которая была бы навсегда закрыта, если бы смерть не высвобождала человека из рабства земле ${ }^{18}$. Смерть во всех отношениях преодолена благодаря воскресению Христову, поправшему ад. Самым страшным аспектом смерти для ветхозаветного народа израильского была окончательная, непреодолимая отделенность от Бога. Шеол был местом безвозвратного отсутствия Господа, разлуки с Ним. Воскресший Христос, сходя в глубины адовы, положил конец разлуке с Богом в смерти. Человек предстает перед Его Лицом, перед Тем, Кто есть Спасение: „Я пришел не судить мир, но спасти мир..." ${ }^{19}$.

Человек должен победить зло и вернуть разрушенный тварный мир, обратясь вновь к Господу, исцеляя случившееся и ведя тварь в Царство Божие. „Мы недостаточно понимаем масштаб нашего христианского призвания; недостаточно понимаем, что и мы призваны со Христом и подобно Христу преобразить мир. Он нас называет детьми света, когда Себя называет Светом мира. Мы должны бы, подобно Ему, быть светом, пронизывающим тьму, отнимающим у тьмы ее темноту, ее непроглядность. Христианин - это человек, которому Бог поручил заботу о других людях, о мире, заботу обо всем" 20 .

Как же человек становится верующим? Митрополит Антоний утверждает, что Бога никто выдумать не может. „Можно выдумать идолов, можно выдумывать чудовищ, которые собой представляют человека, не ограниченного ничем ни в добре, ни во зле; но Того Бога, Который касается глубин души, Который может душу взволновать и наполнить, выдумать невозможно. И всякий человек, который говорит, что он познал Бога в какой бы то ни было мере, в какой бы то ни было форме, - это человек, который коснулся края ризы Божественной, человек, которому Господь открылся, может быть, неуловимо, но открылся"21.

Во вторых, важным условием роста веры - согласно митрополиту Антонию - является чувство голода, тоски, искания, чуда встречи. Архиепископ

17 Cp. ibidem, c. 39-40.

18 Cp. idem, Жизнь. Болезнь. Смерть..., ор. cit., с. 56.

19 Ibidem, c. 84-85.

20 Idem, Бог в нас верит..., ор. cit., с. 41-42.

21 Idem, O путях веры, [в:] idem, Вера, Москва 2013, с. 145. 
Кентерберийский Рамзей считал, на чем заостряет внимание наш автор, что в каждом человеке есть пространство, которое не может быть заполнено ничем иным, как только Божиим присутствием ${ }^{22}$.

По словам митрополита Антония, не существует такого пути человеческой души, где невозможно было бы встретить Господа, но узнать Бога можно только из глубин внутреннего голода и тоски. В Послании к Евреям говорится, что вера - это уверенность в невидимом, а также верность своему исканию, зову, звучащему из самых недр человека. Только если вера становится верностью, если превращается в подвиг верности через молитву, соблюдение Божьих заповедей, можно говорить о раскрытии души до пределов бесконечности, на что обращал внимание Максим Исповедник ${ }^{23}$.

Верующие в Христа принадлежат Церкви. Митрополит Антоний различает Церковь в своем существе от Џеркви, какой ее видит человек. И так, Церковь является Телом Христовым, местом пребывания Духа Святого, обществом святых - людей, всецело, окончательно посвятивших себя Богу. И в то же время верующие - это грешники, мало похожие на Христа - прообраз каждого христианина. Иисус Христос учит: „Я вам дал пример, следуйте ему” (см. Ин. 13, 15). Митрополит Антоний цитирует святого Ефрема Сирина, который утверждал, что Церковь составляет не общество торжествующих святых, только „толпа кающихся грешников... Но разница между теми грешниками, которые составляют Церковь, и теми грешниками, которые Богу чужды, определяется именно этим словом кающиеся. Грешник - это человек, который душой болит о своем отчуждении от Бога, душой болит о том разладе, который царит в нем между всеми силами души и тела, душой болит о том разладе, который существует между ним и его ближними, начиная с самых близких и кончая далекими. И покаяние не заключается только в этом внутреннем глубоком переживании скорби, но также в обращенности к Богу. Скорбеть о себе, об обществе, о своем

22 „В эту глубину, в эту бездонность мы можем кидать все, что земля может дать: и знание, и красоту, и живые чувства; и вместе с этим душа наша никогда не бывает до конца удовлетворена, - остается голод, тоска, желание. И это сознание многих пугает; многие, ощущая в себе эти различные чувства (может, и другие, которые я не назвал), стараются заглушить этот голод, забыться, сузить свою внутреннююемкость, измельчать, если нужно - только бы не раскрыться так, чтобы денно и нощно кричать о своей тоске, о своей растерянности и голоде. А на самом деле, это, возможно, самое драгоценное состояние, какое может у нас быть, потому что только от этого чувства и от осознанности этого чувства может родиться настоящее, серьезное, подвижническое искание того, без чего жить нельзя, а не только искание того, с чем жить было бы легче или удовлетворительнее и приятнее. Такой голод вызывает в душе человека сознание, что чем угодно можно поступиться для того только, чтобы найти то - или Того, Кого душа ищет, Единственного Того, Кто может заполнить, исполнить, преобразить душу, тело, все существо”. Ibidem, c. 145-146. 
Antropologia teologiczna

сиротстве в мире может каждый, но только верующий в Бога может силой этого чувства обратиться к Живому Богу, зная, что Богом Он сотворен, что Богом он любим, что Бог воплотился, стал Человеком для того, чтобы нас спасти - жизнью, учением и смертью и, конечно, Своим Воскресением; и что когда Бог нас зовет быть полностью человеком, Он не говорит о том, чтобы мы были „как можно лучше”, Он говорит о чем-то совершенно ином”24.

В таком случае, как жить по-христиански? Митрополит Антоний находит ответ на этот вопрос в учении Христа: „Я вам дал пример, чтобы вы ему следовали” (см. Ин. 13, 15). Главным критерием жизни верующего является постепенное, возрастающее уподобление Христу, медитируя всю Его жизнь, мышление, Его отношение к человеку и окружающему миру ${ }^{25}$. Рассуждая о роли человека, митрополит Антоний дает совет Иоанна Златоуста: „Если Вы хотите узнать, что такое человек, не поднимайте глаз к престолам царей и вельмож; вознеситесь взором к Престолу Божию, и Вы увидите Человека, сидящего во славе... Единственный Человек, Который полностью, совершенно Человек, это Господь Иисус Христос, потому что в Нем полнота Божества обитала телесно, потому что сама Его телесность пронизана Божеством, потому что Он Бого-Человек; и это - наше призвание"26.

Если в Ветхом Завете отношение к Богу было как бы юридическим, основываясь на исполнении заповедей по совести изо всех своих сил всем своим пониманием всем своим устремлением к праведности, то в Новом Завете Христос подчеркивает, что праведный путь перед Господом не заканчивается на исполнении заповедей: „Когда Вы исполните все, признавайтесь, что вы - неключимые (т.е. никудышные) рабы” (см. Лк. 17, 10)27.

Христианское послушание не базирует на раболепном выполнении жизненных правил, а на умении слушать, проникая в мысли, опыт, понимание, знание, чувство единственного Наставника - Иисуса, который Сам о Себе говорит: „Я - единственный ваш Наставник, Я - единственный ваш Учитель” (см. Мф. 23, 8) 28 .

$24 \quad$ Ibidem, c. $142-143$.

25 Cр. idem, Ожизни христианской, [в:] Idem, Пути христианской жизни, Москва 2011, c. 51.

26 Idem, О путях верық..., ор. cit., c. 143-144.

27 Cp. idem, О жизни христианской..., ор. сіt., с. 51-52.

28 Митрополит Антоний рассуждает: „Когда Христос дает нам заповедь, Он нам не только указывает, что делать; Он нам говорит: вот так поступил бы естественно движением сердца, убежденностьюума, стройностью всего своего существа человек, который духовно целен и здоров... И чтобы вырасти в эту меру цельности, надо начать с того, чтобы учиться, как поступать, как думать, как чувствовать, на примере своего наставника. Но „оправдать” себя тем, что, поступая определенным образом, я бываю „прав” перед Богом, нельзя, потому что „правым” человек не бывает; и не потому, что он никогда не может оправдаться, а потому что не в этом дело: заповедь 
Митрополит Антоний подчеркивает, что не всегда исполнения заповедей достаточно для духовного развития. Необходимо также проявление Христовой заботы и любви ко всем нуждающимся, независимо от факта, кем они являются. Все вопросы Христа из отрывка о Страшном суде, об овцах и козлищах ${ }^{29}$ сводятся к одному: „был ты человечен или нет? Если нет, то как же ожидать, что в твою нечеловечность (если можно употребить такое дикое слово) может влиться Божество? Как ты можешь перерасти свою тварность в приобщении к Божественной природе? Как ты можешь приобщиться Богу, если ты даже не человек?.. Не ставится вопрос о том, веришь ли ты и во что ты веришь; самый основной вопрос, как бы та почва, тот фундамент, на котором можно строить: ты человек или нет? Если ты не человек - не о чем говорить даже..." ${ }^{\prime 3}$.

Вторым евангельским примером, на который заостряет внимание митрополит Антоний, рассуждая о христианском призвании человека, является фрагмент Нагорной проповеди Христа: „Не всякий, кто Меня будет называть „Господи, Господи”, войдет в Царство Небесное, а те, которые будут выполнять волю Отца Моего" (см. Мф. 7, 21). Только в ситуации приобщения Богу, в единстве с Ним, человек до конца будет человеком. Сын Божий стал человеком и явил миру пример, как быть человеком в полном смысле этого слова. Митрополит Антоний подчеркивает, что каждый находится на пути к тому, чтобы быть человеком и у каждого этот путь бывает разным, так как кто-то призван к браку, а кто-то к безбрачию, к молчанию или к слову и т. д. Главное помнить, что каждый неповторим для Господа, единственен, а Евангелие, через образ и слова Христа, указывает путь, как стать Человеком ${ }^{31}$.

Митрополит Антоний считает, что главное задание христиан - свидетельствовать в мире о Христе, ибо "недостаточно быть верующим, - надо научиться давать. Никто большей любви не имеет, как тот, который душу свою, жизнь свою положит за другого"з2. А чтобы этого достичь, надо

нам дана, чтобы мы могли вырасти в новую меру понимания и в новые измерения жизни. Поэтому, когда мы говорим о том, чтобы жить по-христиански, речь не идет о том, чтобы в Евангелии или вообще в Новом Завете найти все правила, какие были указаны Спасителем Христом, апостолами, и их выполнять. Ведь можно механически выполнить правило, к которому ты душой никаким образом не приобщен”. Ibidem, c. $52-53$.

„Ввел ли ты бездомного под свой кров? Накормил ли ты голодного? Посетил ли ты больного? Не постыдился ли признаться в том, что ты друг и знакомый человека, посаженного в тюрьму?” и т. д. (см. Мф. 25, 31-46). Cp. ibidem, c. 56-57. 
Antropologia teologiczna начинать с первых шагов: протянутой руки, живого слова и готовности, не взирая на страх в душе, засвидетельствовать о Божьей любви и святости ${ }^{33}$. Только в гармонии с Богом человек способен понять слова Спасителя о любви ближнего. как самого себя. „Мы должны любить самого себя, но не того эмпирического человека, которым мы являемся: самолюбивого, глупого, тщеславного и т. д., а любить того человека, который заложен в глубины наши как возможность и как призвание" 34 . Митрополит Антоний учит, что христианин должен брать пример со святых, которые в определенный момент своей жизни увидели себя в „смертной опасности” духа и изменили свою жизнь во Христе ${ }^{35}$.

Таким образом, митрополит Антоний в своих проповедях значительное место уделяет первоначальному замыслу Божию о человеке, призванному к преображению себя и окружающего мира. Наш автор со скорбью утверждает, что после первородного греха человек так и не научился полноте жизни с Господом, далее неспособен жить вечной жизнью и словом Божиим. Примером христианского роста в вере являются святые, которым удалось в значительной мере возрастать в своем человечестве, прежде всего через молитву и духовный подвиг.

Ключевые слова: антропология, богословская антропология, Митрополит Сурожский Антоний (1914-2003).

33 Cp. ibidem.

„Он [Бог] верит. Он не перестал творить. Он не перестал вызывать к бытию новых и новых людей. Но за тот ответ, который мы Богу даем, разве не будем мы ответственны и по-иному, в обычном смысле этого слова? Когда мы станем перед Ним, уже не оторвавшись, а оторванные смертью от всего того, что нас порабощает земле, -как мы станем перед Ним и какой ответ дадим? Когда мы увидим Христа воскресшего, сидящего одесную Бога и Отца, но носящего на Своей плоти язвы креста, гвоздиные язвы, раны от венца, следы ношения креста? Когда мы увидим Его и поймем, что если бы никого другого не было на земле, может быть, я сам (сама) был бы причиной Его смерти, как, несомненно, каждый из нас, потерявший единство с Богом, даже не ищущий Его всеми силами, всем сердцем, всем умом, всей волей, всей жизнью, - как каждый из нас ответствен за Его воплощение? Без нашего греха не нужно было бы Ему воплотиться для крестной смерти. Когда кто-то бывает убит, желая спасти нас, разве мы можем это забыть? Нет! Но когда Бог делается человеком, когда Он бывает распинаем, умирает, когда душой Своей человеческой Он сходит в ад, в то место, где нет Бога, в место последнего отчуждения, - мы проходим мимо Него”. Idem, Bepa Божия в человека, [в:] idem, Человек..., ор. cit., с. 176. Cp. ibidem, c. 145. 


\section{Bibliografia:}

1. Кырлежев А., Мистик в миру, [в:] А. Сурожский, Человек перед Богом, Москва 2013, с. 10-26.

2. Сурожский А., Быть христианином, Москва 2010.

3. Сурожский А., О некоторых категориях нашего тварного Бытия, [в:], А. Сурожский, Человек, Москва 2012, с. 5-70.

4. Сурожский А., Вера Божия в человека, [в:] А. Сурожский, Пути христианской жизни, Москва 2011, с. 136-153.

5. Сурожский А., Бог в нас верит, Москва 2010.

6. Сурожский А., О призвании человека, [в:] А. Сурожский, Человек перед Богом, Москва 2013, с. 351-371.

7. Сурожский А., Жизнь. Болезнь. Смерть, Москва 2012.

8. Сурожский А., О путях верьь, [в:] А. Сурожский, Вера, Москва 2013, с. 142-161.

9. Сурожский А., О жизни христианской, [в:] А. Сурожский, Пути христианской жизни, Москва 2011, с. 51-62.

10. Фонд „Духовное наследие митрополита Антония Сурожского”, Библиотека-фонд „Русское Зарубежье”, Духовное наследие митрополита Антония Сурожского. Материалы Первой международной конферениии 28-30 сентября 2007 г. Москва, Москва 2008. 